\title{
Leading with inclusion during the COVID-19 pandemic
}

\section{Stronger together}

\begin{abstract}
Lakshmi Warrior, MD, MPH, Christine Y. Kim, MD, Daniel J. Burdick, MD, Daniel J. Ackerman, MD, Luca Bartolini, MD, Kendra R. Cagniart, MD, Neha S. Dangayach, MD, MSCR, Elliot T. Dawson, MD, Karen D. Orjuela, MD, MSCR, Gillian L. Gordon Perue, MD, Jeremy K. Cutsforth-Gregory, MD, Mona N. Bahouth, MD, PhD, Jeffrey C. McClean, II., MD, * and Gabriele C. DeLuca, MD*
\end{abstract}

Neurology ${ }^{\circledR}$ 2020;95:537-542. doi:10.1212/WNL.0000000000010641

\section{Correspondence}

Dr. Warrior

Iwarrior@cookcountyhhs.org

\section{MORE ONLINE}

\section{COVID-19 Resources}

For the latest articles, invited commentaries, and blogs from physicians around the world NPub.org/COVID19

\section{Introduction}

In October 2019, the world felt like a different place. We met in Las Vegas as participants of the 2019-2020 American Academy of Neurology (AAN) Emerging Leaders Program (ELP). The ELP is a 6-month leadership development program sponsored by the AAN and designed to engage 10 early-career members who have demonstrated the potential for and interest in leadership roles within the AAN and the field of neurology. Together, we were charged with the daunting task of recommending bold actions to make the AAN a fully inclusive society. In the following months, we grew as leaders, built friendships across the country, and gained a better understanding of the challenges and the benefits of equity, diversity, and inclusion (EDI). Although as a group we had no prior training in EDI, we collectively came to understand that the practice of inclusion inherently underlies success in every professional goal. The economic argument is clear. Inclusive and diverse organizations are more efficient, outperform others in problem solving, and are overall more productive. ${ }^{1,2}$ We developed a shared definition of inclusion as the deliberate practice of ensuring that each individual is heard, all personal traits are respected, and all can make meaningful contributions to achieve their full potential. We came to understand how a practice of inclusion, which strives to create a sense of belonging for all participants, drives equity, the goal of providing equal opportunity and fair access to resources for all. These related but distinct principles are inseparable: by seeking to include every individual, one becomes aware of inequities that must be resolved to create a sense of belonging for everyone. As coronavirus disease 2019 (COVID-19) spreads globally and across the United States, we have viewed this pandemic through the lens of both equity and inclusion. Here, we discuss how this pandemic has magnified preexisting health and social disparities and will both summarize why inclusion is an essential tool to traverse this uncertain terrain and discuss specific steps health care organizations can take to improve these disparities.

\footnotetext{
*These authors contributed equally.
}

From the Division of Neurology (L.W.), Cook County Health, Chicago, IL; Department of Neurology (C.Y.K.), Yale School of Medicine, New Haven, CT; Evergreen Health Neuroscience Institute (D.J.B.), Evergreen Health Medical Center, Kirkland, WA; Department of Neurology (D.J.A.), St. Luke's University Health Network, Bethlehem, PA; Rhode Island Hospital/The Warren Alpert Medical School of Brown University (L.B.), Providence; Department of Neurology (K.R.C.), Fort Belvoir Community Hospital, VA; Icahn School of Medicine at Mount Sinai (N.S.D.), New York; Division of Neurology (E.T.D.), MedStar Franklin Square Medical Center, Baltimore, MD; Department of Neurology (K.D.O.), University of Colorado, Aurora; Department of Neurology (G.L.G.P.), University of Miami-Miller School of Medicine, FL; Department of Neurology (.K.C.-G.), Mayo Clinic, Rochester, MN; Department of Neurology (M.N.B.), Johns Hopkins School of Medicine, Baltimore, MD; San Antonio Military Medical Center (J.C.M.), TX; and University of Oxford (G.C.D.), Oxford, United Kingdom.

Go to Neurology.org/N for full disclosures. Funding information and disclosures deemed relevant by the authors, if any, are provided at the end of the article. 


\section{Glossary}

AAN = American Academy of Neurology; COVID-19 = coronavirus disease 2019; EDI = equity, diversity, and inclusion; ELP = Emerging Leaders Program; IMG = international medical graduate.

\section{Disproportionate effects of COVID-19 on vulnerable populations and patients with neurologic disease}

Although we have all been affected by COVID-19, this virus disproportionately affects our most vulnerable populations, ${ }^{3,4}$ including those with neurologic disease. Preliminary studies have shown that comorbidities including diabetes, hypertension, coronary artery disease, and cerebrovascular disease are associated with higher mortality. ${ }^{5,6}$ Racial and ethnic disparities in chronic disease, including diabetes and hypertension, have been described previously ${ }^{7,8}$ and may contribute to the currently observed disparities in mortality and severity of COVID-19. There have been early reports of significantly higher infection and mortality rates among African Americans, as one example. ${ }^{9,10}$ Poverty, disproportionate representation among essential workers, reduced health literacy, a generational mistrust of health care institutions, restrictions in housing due to redlining, and limitations in access to adequate health care may all contribute to the disparities in infection, transmission, and mortality rates.

This pandemic has exacerbated many preexisting social disparities, leaving marginalized populations at particular risk for poor access to care. Individuals with disabilities, ${ }^{11}$ people experiencing homelessness, ${ }^{12}$ immigrants, and people who selfidentify as Lesbian, Gay, Bisexual, Transgender, and Queer or Questioning (LGBTQ) ${ }^{13}$ are at risk of disparities in both COVID-19-related morbidity and indirect sequelae resulting from decreased access to care for other medical conditions and social services during the pandemic. Although telemedicine has been implemented as a potential solution to limits in face-toface visits, we have concerns about the populations who may not have equal access to these technologies because of the digital divide. These populations notably include many of our patients with neurologic disease, especially those who are elderly, have cognitive or motor impairment that limits use of technology, are experiencing homelessness, or require interpreter services.

Although the clinical manifestations of COVID-19 among children are still emerging, the disruption to their lives is definite. ${ }^{14}$ This is particularly true among children in marginalized populations or with preexisting neurologic disease. It is estimated that 114,000 school-age students in New York City alone experience homelessness; with COVID-19-related school closures, many of these children have lost a critical support structure. ${ }^{15}$ For many children, school was not only a place for learning but also a source of necessary shelter, food, protection, and social support. Children with chronic neurologic disabilities may be particularly vulnerable as they face the loss of multidisciplinary support crucial to the management of their disability. Another important group is the elderly, who often rely on support outside the home. ${ }^{16}$ Although isolation may prevent transmission, there is concern for groups such as the elderly who may already feel isolated and lonely. ${ }^{16}$

As neurologists, we are particularly concerned that in the setting of COVID-19, our patients with unrelated neurologic disease may not have their needs met. As our hospital floors and intensive care units are running at capacity with patients with COVID-19, it has been reported that patients without COVID19 with neurologic emergencies, such as stroke, are not seeking the care they require. ${ }^{17}$ In addition, our patients may be disproportionately affected by access issues. Patients with cognitive or motor disorders may have additional difficulties steering themselves through the new hurdles of the changes to our health system. Patients with multiple sclerosis, myasthenia gravis, and other diseases requiring immunosuppression may be particularly susceptible to COVID-19. Consequently, these patients may need to socially distance themselves more aggressively, potentially leading to decreased access to care and inability to receive required home care and community support. Mental health issues have been significant amid the social isolation and stressors of this pandemic. Given the comorbidity of mental illness such as depression and anxiety with neurologic disease, we are concerned that our patients may also be disproportionately affected.

\section{Impact of COVID-19 on the health care system and the neurology workforce}

The battle against COVID-19 has placed a heavy weight on our health system and has significantly affected the well-being of both individual health care workers ${ }^{18}$ and health care systems as a whole. Hospital systems and health care practices face significant financial pressures due to loss of revenue from canceled elective procedures and deferred ambulatory care and higher expenses associated with global supply shocks. These translate into furloughed workers, delays in capital improvements, and potential hospital closures in at-risk rural communities. ${ }^{19}$ Again, those individuals, systems, and communities at greatest risk are those that were marginalized before the pandemic. Increased risk to personal health sometimes comes with the practice of health care, but few foresaw themselves forced to plead for personal protective equipment on social media ${ }^{20}$ or expected the invisible mental health toll of the pandemic on health care workers who responded to the call of the frontlines. These workers have taken on enormous personal risk, isolated 
themselves from the family to prevent spread while simultaneously experiencing an unprecedented level of death and dying. Neurologists specifically may be at increased risk: although the virus itself may not be discriminating, the workforce of US neurologists is older and predominantly male and therefore may, as a group, have poorer outcomes with COVID$19 .^{21}$ Although early reports suggest that men are disproportionately affected by COVID-19 with higher infection rates and mortality, ${ }^{22}$ women also confront immense challenges during this epidemic. ${ }^{23}$ Women account for over $70 \%$ of the world's health care force ${ }^{24}$ and perform almost 2.5 times more unpaid and domestic work as men. ${ }^{25}$ Despite the disproportionate burden of unpaid labor, women also account for the majority of essential workers. ${ }^{26}$ The balance between expanding professional responsibilities and the complexity of childcare responsibilities during prolonged school closures has been a significant challenge for many. In addition, our colleagues who have immigrated to the United States to practice neurology, who already face high risks of negative workplace bias, now struggle to cope with infected family and friends in their countries of origin and visa barriers during travel restrictions. ${ }^{27}$ As we weather the changes to our workplace and scope of practice, we must be aware of these potential impacts to our colleagues and their families and our patients.

We are particularly concerned by reports of rising racial and ethnic intolerance. During this pandemic, fear has become an almost universal sentiment. History teaches us that with fear can come hatred, intolerance, and stigmatization. With the rise of COVID-19 has come an increase in racist rhetoric, misinformation, and violence against Asians and those of Asian descent. ${ }^{28-30}$ This is a concern not only for society as a whole but also specifically for our patients and our colleagues. Over $20 \%$ of AAN members identify as Asian or of Asian descent. ${ }^{20}$ In addition, there have been reports of health care workers facing ostracism from their communities and discrimination. ${ }^{30,31}$ This is the starkest example of lack of inclusion and cripples our ability to effectively respond to the magnitude of COVID-19. Furthermore, we have a moral imperative to ensure that such acts of intolerance do not affect the care of our patients or the health and safety of our colleagues. History has also taught us that the deliberate practice of inclusion through advocacy and education can overcome fear and intolerance. With an inclusive approach, a global health crisis can be turned into an opportunity to improve our social and physical health. As an example, the public health response in the United States and Europe to the 19th century scourges of typhoid and cholera, which also had a disproportionate impact on marginalized members of society, led to a decades-long effort to overhaul our sewer and sanitation practices and culminated in improved overall public health. ${ }^{32}$

\section{A bold call to action: Proposed solutions for the AAN}

To this point, we have summarized the many inequities that COVID-19 has exposed and exacerbated. Now we will highlight solutions for the AAN, neurologists, and health care systems. Specifically, we feel that creating a culture of inclusion, with a focus on the deliberate act of listening to each person's perspective, drives equitable solutions to these problems in each arena. One cannot address a specific need without first being aware of it. As the practice of inclusion brings awareness of each person's needs, the pursuit of equity then compels us to act on that knowledge.

Over the last 5 years, the AAN has made a concerted effort to build diversity, equity, and inclusion into the Academy and can use the challenges presented by COVID-19 as an opportunity to expand its leadership role in promoting equity through inclusion. In 2015, the President of the AAN established the Diversity Task Force. Over the next 4 years, the Diversity Leadership Program, Diversity Officers' Workgroup, the LGBTQ Section, the first Women Leading in Neurology program, the Healthcare Disparities Task Force, and the Equity, Diversity and Inclusion Joint Coordinating Council were all established. These programs have laid a foundation in which change throughout the organization can be made, and now is the time to use this organizational structure to answer the challenges of COVID-19.

Our 6 recommendations for the AAN are as follows:

1. Establish and promote a culture of inclusion. True inclusion is about the culture of an organization. Work must be done to ensure the shared belief that all members are heard, personal traits are respected, and all can make meaningful contributions to achieve their full potential. Although equity and diversity are named as core values for the AAN, inclusion is not. Inclusion needs to be clearly stated as a core value to begin building this culture. We feel that a lack of understanding is the most significant threat to EDI. By promoting and expanding education about EDI throughout the AAN to our members, committees, leadership, and publications, we can begin building this culture. This pandemic has highlighted vulnerable populations in both our workforce and the populations we serve. Education on inclusion will help bring the voices of even the most vulnerable individuals to the forefront, ensuring that issues of equity are understood and addressed. Educational programs on inclusion can include implicit bias training, crucial conversation role playing, training to identify microaggressions, and cross-cultural communications enabling members and leaders to identify everyday opportunities for inclusivity. The culture of inclusion can be further built by making statements of inclusion in all communications and expanding public marketing of EDI messaging.

2. Measure inclusion specifically. Although diversity is easily measured and measures of equity can be objectively assessed, inclusion must be separately assessed. Inclusion is based on subjective experience, requiring each person to feel a sense of belonging. Therefore, we recommend a biannual survey of inclusion for all members to measure inclusion within the organization with a goal of improvement of $5 \%$ at 2 years and $15 \%$ at 6 years. 
3. Build accountability for leadership. Buy-in from leadership is essential for an inclusive culture. To help ensure that appropriate vision, strategy, personnel, and resources are available, leadership should provide for timely transparency for the above metric and goals. Stakeholders may empower themselves by implementing a scorecard or clearly, predefined benefits and potential restrictions based on success or failure, respectively. Last, organizations should provide appropriate vertical access to leadership throughout the structure of organizations.

4. Build inclusion into our pathways to leadership in the AAN and support advancement of inclusion at individual institutions and practices. This can be operationalized by formalizing a transparent and inclusive process for committee membership and leadership positions, both at the AAN and at home institutions. Expansion of existing mentorship programs, such as including every committee member in a mentorship program, will also strengthen inclusion. Furthermore, by leveraging and expanding initiatives such as the Diversity Officers' Workgroup, the AAN should support and promote institutional diversity officers who build inclusion at the level of individual departments and practices. By integrating inclusion into everyday practice, we change our approach and response to future crises like COVID-19.

5. Publications and scientific programs within the AAN must continue to raise the standard for excellence and inclusion. The Academy can actively solicit journal articles related to health care inequities in neurology or the effects of inclusion on the care of patients with neurologic disease or on the practice of neurology. Furthermore, dedicated support of research characterizing health care disparities and effective strategies for mitigation is critical in achieving inclusion for all individual patients, both now during COVID-19 and beyond.

6. Employ advocacy groups to influence political structures and policymakers to promote inclusion in private organizations and public society. The AAN can employ Neurology on the Hill to highlight how COVID-19 affects our patients and providers. The AAN could potentially advocate for wider access to broadband services in rural communities, thereby decreasing the digital divide and increasing access to telehealth services. As the largest neurologic society in the world, it is important that the AAN continue advocacy for a fair immigration process for our international medical graduate (IMG) members and their families with an active immigration process affected by delays in visa renewals or visa sponsorship processes. It is critical as a community to create a safe environment for our IMGs to continue their crucial clinical or research activities during this pandemic.

\section{A bold call to action: Specific actions for neurologists and health care systems}

Although we are physically distant, we need to stand together to fight fear and intolerance as a professional and global community. It is critical that we work together to recognize and dispel misconceptions while standing united to support our colleagues and patients. Adopting an inclusive approach to treating COVID-19 by accounting for health disparities and striving for inclusion and equity in our response and care deployment plan will better address the individual needs of our patients and our system's health care workers. Only by identifying vulnerable individuals and including their voices in the conversation can we dampen the inequitable effects of this pandemic. Precisely because this virus does not discriminate, it will continue to circulate and reemerge unless we adopt an inclusive approach. We must strive to support and include our colleagues and fellow health care workers to ensure that they are safe and are treated with the respect and dignity they deserve.

Health care systems have a dual responsibility to their patients and to their employees. We recommend first that health care systems develop and implement specific outreach programs to identify vulnerable patients and work to meet their needs; examples include outreach to nursing homes and increasing access to testing for vulnerable populations. Second, health care systems should look inward, reaching out to employees who are made more vulnerable by this crisis and developing an inclusive approach to ameliorating these vulnerabilities, for example, providing mental health services for employees or childcare services to essential hospital workers. On an individual level, consider your own practice: does every colleague and employee have an equal voice? Are there people who are more at risk from the effects COVID-19 and need greater support? How can you build inclusion into your practice? Consider your patients. How can you provide support for those patients who are made more vulnerable by this pandemic? Is there a voice among your patients that is not being heard? How can you give them a voice?

As COVID-19 spreads throughout global communities and across the United States, it has forced us to face new realities of everyday life. Under mandates of social distancing, feelings of isolation, loneliness, and fear penetrate our everyday lives. This should not threaten our pursuit of a highly inclusive society and indeed strengthens the need to build connections across differences. If every one of us takes our responsibility to pursue inclusion seriously, we can be confident that each individual is heard, that all personal traits are respected, and each of us is able to achieve our potential no matter the challenge before us. This pandemic only reinforces the need for the improved efficiency, productivity, and problem solving that inclusion brings.

As physicians, we are in a new world. For some of us, this means converting our face-to-face visits to telephone or virtual visits. For others, it means fighting on the front lines against this invisible enemy in the intensive care unit or on the hospital floors. Whether facing the fear of working without essential personal protective equipment or the discomfort of caring for a 
broader patient population beyond our usual focus, we are in uncharted territory. More than ever before, we need each other. Regardless of our individual experiences, adapting to the new normal and fighting for a healthier, more inclusive and equitable future is something we do together. In this time of uncertainty, there is one clear truth: our world is changed forever. But with change comes opportunity. Let us work together to build a stronger, more inclusive future. \#AANstrongerTogether \#AANmeansInclusion.

\section{Acknowledgment}

The authors acknowledge Amy Nostdahl, Barbara Hoese, and Sarah Dietman. Their continued mentorship and support throughout this journey have been invaluable. The authors thank them for helping build them into the leaders they wanted to be.

\section{Study funding}

No targeted funding reported.

\section{Disclosure}

The authors report no disclosures relevant to the manuscript. Go to Neurology.org/N for full disclosures.

\section{Publication history}

Received by Neurology April 23, 2020. Accepted in final form July 31,2020 .

\begin{tabular}{|c|c|c|}
\hline Name & Location & Contribution \\
\hline $\begin{array}{l}\text { Lakshmi } \\
\text { Warrior, MD, } \\
\text { MPH }\end{array}$ & $\begin{array}{l}\text { Division of Neurology, Cook } \\
\text { County Health, Chicago }\end{array}$ & $\begin{array}{l}\text { Conceptualized the } \\
\text { study and drafted the } \\
\text { manuscript }\end{array}$ \\
\hline $\begin{array}{l}\text { Christine Y. } \\
\text { Kim, MD }\end{array}$ & $\begin{array}{l}\text { Department of Neurology, } \\
\text { Yale School of Medicine, New } \\
\text { Haven, CT }\end{array}$ & $\begin{array}{l}\text { Conceptualized the } \\
\text { study and major } \\
\text { revisions to the } \\
\text { manuscript }\end{array}$ \\
\hline $\begin{array}{l}\text { Daniel J. } \\
\text { Burdick, MD }\end{array}$ & $\begin{array}{l}\text { Evergreen Health } \\
\text { Neuroscience Institute, } \\
\text { Evergreen Health Medical } \\
\text { Center, Kirkland, WA }\end{array}$ & $\begin{array}{l}\text { Conceptualized the } \\
\text { study and major } \\
\text { revisions to the } \\
\text { manuscript }\end{array}$ \\
\hline $\begin{array}{l}\text { Daniel J. } \\
\text { Ackerman, } \\
\text { MD }\end{array}$ & $\begin{array}{l}\text { Department of Neurology. St. } \\
\text { Luke's University Health } \\
\text { Network, Bethlehem, PA }\end{array}$ & $\begin{array}{l}\text { Conceptualized the } \\
\text { study and revised the } \\
\text { manuscript }\end{array}$ \\
\hline $\begin{array}{l}\text { Luca } \\
\text { Bartolini, MD }\end{array}$ & $\begin{array}{l}\text { Rhode Island Hospital/The } \\
\text { Warren Alpert Medical School } \\
\text { of Brown University, } \\
\text { Providence, RI }\end{array}$ & $\begin{array}{l}\text { Conceptualized the } \\
\text { study and revised the } \\
\text { manuscript }\end{array}$ \\
\hline $\begin{array}{l}\text { Kendra R. } \\
\text { Cagniart, MD }\end{array}$ & $\begin{array}{l}\text { Department of Neurology, } \\
\text { Fort Belvoir Community } \\
\text { Hospital, VA }\end{array}$ & $\begin{array}{l}\text { Conceptualized the } \\
\text { study and revised the } \\
\text { manuscript }\end{array}$ \\
\hline $\begin{array}{l}\text { Neha S. } \\
\text { Dangayach, } \\
\text { MD, MSCR }\end{array}$ & $\begin{array}{l}\text { Icahn School of Medicine at } \\
\text { Mount Sinai, NY }\end{array}$ & $\begin{array}{l}\text { Conceptualized the } \\
\text { study and revised the } \\
\text { manuscript }\end{array}$ \\
\hline $\begin{array}{l}\text { Elliot T. } \\
\text { Dawson, MD }\end{array}$ & $\begin{array}{l}\text { Division of Neurology, } \\
\text { MedStar Franklin Square } \\
\text { Medical Center, Baltimore, MD }\end{array}$ & $\begin{array}{l}\text { Conceptualized the } \\
\text { study and revised the } \\
\text { manuscript }\end{array}$ \\
\hline
\end{tabular}

Neurology.org/N

\begin{tabular}{lll} 
Appendix & (continued) & \\
\hline Name & Location & Contribution \\
\hline $\begin{array}{l}\text { Karen D. } \\
\text { Orjuela, MD, } \\
\text { MSCR }\end{array}$ & $\begin{array}{l}\text { Department of Neurology, } \\
\text { University of Colorado, Aurora }\end{array}$ & $\begin{array}{l}\text { Conceptualized the } \\
\text { study and revised the } \\
\text { manuscript }\end{array}$ \\
\hline $\begin{array}{l}\text { Gillian L. } \\
\text { Gordon } \\
\text { Perue, MD }\end{array}$ & $\begin{array}{l}\text { Department of Neurology, } \\
\text { Schiversity of Miami-Miller }\end{array}$ & $\begin{array}{l}\text { Conceptualized the } \\
\text { study and revised the } \\
\text { manuscript }\end{array}$ \\
\hline $\begin{array}{l}\text { Jeremy K. } \\
\text { Cutsforth- } \\
\text { Gregory, MD }\end{array}$ & $\begin{array}{l}\text { Department of Neurology, } \\
\text { Mayo Clinic, Rochester, MN }\end{array}$ & $\begin{array}{l}\text { Conceptualized the } \\
\text { study and revised the } \\
\text { manuscript }\end{array}$ \\
\hline $\begin{array}{l}\text { Mona N. } \\
\text { Bahouth, } \\
\text { MD, PhD. }\end{array}$ & $\begin{array}{l}\text { Department of Neurology, } \\
\text { Johns Hopkins School of }\end{array}$ & $\begin{array}{l}\text { Conceptualized the } \\
\text { study and revised the } \\
\text { manuscript }\end{array}$ \\
\hline $\begin{array}{l}\text { Jeffrey C. } \\
\text { McClean II, } \\
\text { MD }\end{array}$ & $\begin{array}{l}\text { San Antonio Military Medical } \\
\text { Center, TX }\end{array}$ & $\begin{array}{l}\text { Conceptualized the } \\
\text { study and revised the } \\
\text { manuscript }\end{array}$ \\
\hline $\begin{array}{l}\text { Gabriele C. } \\
\text { DeLuca, MD }\end{array}$ & $\begin{array}{l}\text { University of Oxford, Oxford, } \\
\text { United Kingdom }\end{array}$ & $\begin{array}{l}\text { Conceptualized the } \\
\text { study and revised the } \\
\text { manuscript }\end{array}$ \\
& &
\end{tabular}

\section{References}

1. Hsieh CT, Hurst E, Jones CI, Klenow PJ. The allocation of talent and U.S. Economic Growth. Econometrica 2019;87:1439-1474.

2. Hong L, Page SE. Groups of diverse problem solvers can outperform groups of highability problem solvers. Proc Natl Acad Sci U S A 2004;101:16385-16389.

3. Wang Z, Tang K. Combating COVID-19: health equity matters. Nat Med 2020;26: 458.

4. Devakumar D, Shannon G, Bhopal SS, Abubakar I. Racism and discrimination in COVID-19 responses. Lancet 2020;395:1194.

5. Zhou F, Yu T, Du R, et al. Clinical course and risk factors for mortality of adult inpatients with COVID-19 in Wuhan, China: a retrospective cohort study. Lancet 2020;395:1054-1062.

6. Onder G, Rezza G, Brusaferro $S$. Case-fatality rate and characteristics of patients dying in relation to COVID-19 in Italy. JAMA Epub 2020 Mar 23.

7. Kurian AK, Cararelli KM. Racial and ethnic differences in cardiovascular disease risk factors: a systematic review. Ethn Dis 2007;17:143-152.

8. Pool LR, Ning H, Lloyd-Jones DM, Allen NB. Trends in racial/ethnic disparities in cardiovascular health among US adults from 1999-2012. J Am Heart Assoc 2017;6: e0060207.

9. Johnson A, Buford T. Early Data Shows African Americans Have Contracted and Died of Coronavirus at an Alarming Rate. Available at: propublica.org/article/earlydata-shows-african-americans-have-contracted-and-died-of-coronavirus-at-an-alarming-rate. Accessed April 5, 2020.

10. Zamudio MI. In Chicago, $70 \%$ of COVID-19 Deaths are Black. Available at: wbez. org/shows/wbez-news/in-chicago-70-of-covid19-deaths-are-black/dd3f295f-445e4e38-b37f-a1503782b507/amp. Accessed April 5, 2020.

11. Armitage R, Nellums LB. The COVID-19 response must be disability inclusive. Lancet Public health 2020;5:e257.

12. Tsai J, Wilson M. COVID-19: a potential public health problem for homeless populations. Lancet Public health 2020;5:e186-e18e7.

13. Human Rights Watch. Human Rights Dimensions of COVID-19 Responses. Available at: hrw.org/news/2020/03/19/human-rights-dimensions-covid-19-response. Accessed April 10, 2020.

14. Dong Y, Mo X, Hu Y, Qi X, Jiang F, Tong S. Epidemiological characteristics of 2143 pediatric patients with 2019 coronavirus disease in China. Pediatrics 2020; e20200702.

15. Stewart N. She's 10, Homeless and Eager to Learn. But She Has No Internet. 2020. The New York Times. Available at: nytimes.com/2020/03/26/nyregion/new-yorkhomeless-students-coronavirus.html). Accessed April 9, 2020.

16. Artmitage R, Nellums LB. COVID-19 and the consequences of isolating the elderly. Lancet Public Health 2020;5:e256.

17. Chen M. How Hospitals Can Maintain Essential Health Care. US News and World Report: Commentary. 2020. Available at: usnews.com/news/healthiest-communities/articles/2020-04-09/do-we-have-to-choose-between-stroke-or-covid-19patients. Accessed April 10, 2020

18. Adams JG, Walls RM. Supporting the health care workforce during the COVID-19 global epidemic. JAMA Epub 2020 Mar 12.

19. Mathews AW, Evans M. Hospitals, Doctors feel financial squeeze as coronavirus sweeps U.S. Wall Street Journal [online]. Available at: wsj.com/articles/hospitalsdoctors-feel-financial-squeeze-as-coronavirus-sweeps-u-s-11585768706. Accessed April 10, 2020. 
Padilla M. "It Feels like a War Zone": Doctors and Nurses Plead for Masks on Social Media. The New York Times [online]. Available at: nytimes.com/2020/03/19/us/ hospitals-coronavirus-ppe-shortage.html. Accessed April 10, 2020.

21. American Academy of Neurology. 2020 Insights Report: A Report from the Member Research Subcommittee of the American Academy of Neurology.

22. Chen N, Zhou M, Dong X, et al. Epidemiological and clinical characteristics of 99 cases of 2019 novel coronavirus pneumonia in Wuhan, China: a descriptive study. Lancet 2020;395:507-513.

23. Wenham C, Smith J, Morgan R. COVID-19: the gendered impacts of the outbreak Lancet 2020;395:846-848.

24. Boniol M, McIsaac M, Xu L, Wuliji T, Diallo K, Campbell J. Gender Equity in the Health Workforce: Analysis of 104 Countries. Working Paper 1. Geneva: World Health Organization; 2019. Available at: apps.who.int/iris/bitstream/handle/10665/ 311314/WHO-HIS-HWF-Gender-WP1-2019.1-eng.pdf?sequence=1\&isAllowed=y. Accessed April 11, 2020

25. UN Woman. Progress of the World's Women 2015-2016. Available at: unwomen. org/-/media/headquarters/attachments/sections/library/publications/2015/poww2015-2016-en.pdf?la=en\&vs=0. Accessed April 11, 2020.
Robertson C, Gebeloff R. How Millions of Women Became the Most Essentia Workers in America. Available at: nytimes.com/2020/04/18/us/coronaviruswomen-essential-workers.html. Accessed May 16, 2020.

27. White AIR. Historical linkages: epidemic threat, economic risk, and xenophobia. Lancet 2020;395:1250-1251.

28. Schoichet CE. What Historians Hear when Trump Calls Coronavirus "Chinese" and "foreign". 2020. Available at: cnn.com/2020/03/12/us/disease-outbreaks-xenophobia-history/index.html. Accessed April 5, 2020.

29. Avalos G. Irate Subway Passenger Sprays Asian Man with Air Freshner over Coronavirus Concerns. 2020. Available at: nbcnewyork.com/news/coronavirus/iratesubway-passenger-sprays-asian-man-with-air-freshener-over-coronavirus-concerns/ 2316216/. Accessed April 5, 2020

30. Yeung J, Gupta S. Doctors Evicted from Their Homes in India as Fear Spreads Amid Coronavirus Lockdown. 2020. Available at: cnn.com/2020/03/25/asia/india-coronavirus-doctors-discrimination-intl-hnk/index.html. Accessed April 5, 2020.

31. Pandey V. Coronavirus: India Doctors "Spat at and Attacked". 2020. Available at: bbc. com/news/world-asia-india-52151141. Accessed April 5, 2020.

32. Snowden F. Epidemics and Society. New Haven, CT: Yale University Press; 2019.

\section{Announcing... \\ Child Neurology: A Case-Based Approach Cases from the Neurology ${ }^{\circ}$ Resident \& Fellow Section}

This collaboration between the American Academy of Neurology (AAN) and the Child Neurology Society (CNS) represents a collection of reprinted cases from the past 15 years from the Neurology Resident \& Fellow Section.

An invaluable resource for both adult and pediatric neurologists and trainees! FREE download: NPub.org/cnbook

\section{Visit the Neurology ${ }^{\circledast}$ Resident \& Fellow Website}

Click on Residents \& Fellows tab at Neurology.org.

Now offering:

- Neurology ${ }^{\circledR}$ Resident \& Fellow Editorial team information

- "Search by subcategory" option

- E-pearl of the Week

- RSS Feeds

- Direct links to Continuum ${ }^{\circledR}$, Career Planning, and AAN Resident \& Fellow pages

- Recently published Resident \& Fellow articles

- Podcast descriptions

- Blogs by Editors and Resident \& Fellow team members

f Find Neurology ${ }^{\circledR}$ Residents \& Fellows Section on Facebook: facebook.com/AANResidentsAndFellows

Follow Neurology ${ }^{\circledR}$ on Twitter: @GreenJournal \#NeurologyRF

(ㅇ) Find Neurology ${ }^{\circledR}$ Residents \& Fellows Section on Instagram: @aanbrain \#NeurologyRF 


\section{Neurology}

\section{Leading with inclusion during the COVID-19 pandemic: Stronger together}

Lakshmi Warrior, Christine Y. Kim, Daniel J. Burdick, et al.

Neurology 2020;95;537-542 Published Online before print August 14, 2020

DOI 10.1212/WNL.0000000000010641

This information is current as of August 14, 2020

\section{Updated Information \&}

Services

\section{References}

\section{Citations}

Subspecialty Collections

Permissions \& Licensing

Reprints including high resolution figures, can be found at:

http://n.neurology.org/content/95/12/537.full

This article cites 13 articles, 1 of which you can access for free at: http://n.neurology.org/content/95/12/537.full\#ref-list-1

This article has been cited by 2 HighWire-hosted articles: http://n.neurology.org/content/95/12/537.full\#\#otherarticles

This article, along with others on similar topics, appears in the following collection(s): Bias, prejudice, discrimination

http://n.neurology.org/cgi/collection/bias_prejudice_discrimination Health disparities

http://n.neurology.org/cgi/collection/health_disparities

Inclusion, Diversity, Equity, Anti-racism, and Social Justice (IDEAS)

http://n.neurology.org/cgi/collection/all_equity_diversity_and_inclusion

Workforce diversity

http://n.neurology.org/cgi/collection/workforce_diversity

Information about reproducing this article in parts (figures,tables) or in its entirety can be found online at:

http://www.neurology.org/about/about_the_journal\#permissions

Information about ordering reprints can be found online:

http://n.neurology.org/subscribers/advertise

Neurology ${ }^{\circledR}$ is the official journal of the American Academy of Neurology. Published continuously since 1951, it is now a weekly with 48 issues per year. Copyright (C) 2020 American Academy of Neurology. All rights reserved. Print ISSN:

0028-3878. Online ISSN: 1526-632X.

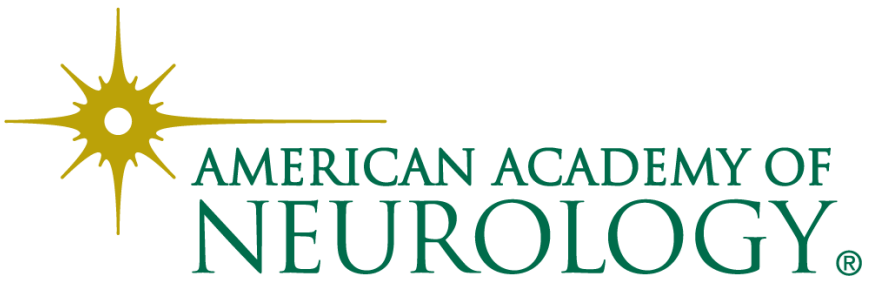

